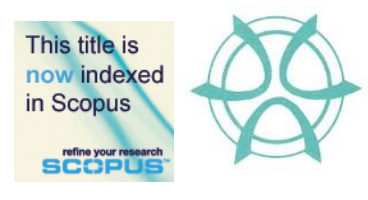

PLANNING MALAYSIA:

Journal of the Malaysian Institute of Planners

SPECIAL ISSUE V (2016), Page 115 - 128

\title{
PREVENTION OF AEDES BREEDING HABITATS FOR URBAN HIGH-RISE BUILDING IN MALAYSIA
}

\author{
Nurshuhada Zainon ${ }^{1}$, Faizul Azli Mohd Rahim ${ }^{2}$, Dalila Roslan ${ }^{3}$ \& Azlan Helmy \\ Abd-Samat ${ }^{4}$ \\ ${ }^{1,2}$ Centre for Building, Construction, \& Tropical Architecture \\ Faculty of Built Environment \\ UNIVERSITY OF MALAYA \\ ${ }^{3}$ Department of Community Health Medicine \\ ${ }^{4}$ Department of Emergency \\ UKM Medical Center \\ UNIVERSITI KEBANGSAAN MALAYSIA
}

\begin{abstract}
Dengue is endemic in Malaysia; it is found mainly in the urban and suburban areas. Aedes Aegypti and Aedes Albopictus have been incriminated in the transmission of dengue virus in many urban areas of South-East Asia, including Malaysia. Dengue cases that have been reported worldwide were related with high rise buildings especially in residential buildings such as apartments and condominiums. This study aims to identify the breeding habitats resulted from building designs in high-rise apartments in Kuala Lumpur, Malaysia. Inspections were conducted at three dengue-hotspots residential buildings located in Lembah Pantai, Kuala Lumpur. The selection criteria of the study sites were based on the most frequent reports on dengue cases from these three localities. The building elements that Aedes breeding were spotted created semi-permanent areas for Aedes breeding. Findings show the buildings were designed with unreachable rain gutters, making checking and cleaning for mosquito breeding in clogged gutters impossible for local residents. Poor drainage and piping system has found to be the Aedes habitats, too. Of these, surprisingly, uneven surface of the concrete rooftops and floors has also become one of the breeding spots, resulting to water stagnation and liveable areas for Aedes to breed. Correlating this findings not only helps target areas to be identified and focused in community search and destroy programs, but most importantly it contributes to high-rise building design and construction features in Malaysia by taking into considerations long-lasting measures for a holistic sustainable environment.
\end{abstract}


Nurshuhada Zainon, Faizul Azli Mohd Rahim, Dalila Roslan \& Azlan Helmy Abd-Samat

Aedes Breeding Preferences for Urban High-Rise Building Planning Considerations in Malaysia

Keyword: Aedes, dengue, high-rise building, prevention, sustainable neighbourhood.

\section{INTRODUCTION}

Dengue endemic in Malaysia is alarming as reported dengue cases skyrocketed placing Malaysia third highest among the Western Pacific Region countries Mohd-Zaki, Brett, Ismail \& L'Azou, 2014). Yearly comparison released by the Malaysian Ministry of Health (MOH) highlighted 250\% increment of incidence rate in the year 2014 as compared to same period in year 2013 and claiming the lives of 101 people in 2015 as compared to only 59 people in 2014 (Astro Awani, March 31, 2015). Empirical findings of trend and pattern of dengue and the associated dengue virus serotypes alert us that dengue outbreaks is expected to occur continuously in Malaysia throughout the $21^{\text {st }}$ century (Abubakar \& Shafee, 2002).

People infected by dengue fever will have high fever, and at least two of the following symptoms: severe headache, severe eye pain, joint pain, muscle and/or bone pain, rash, mild bleeding, and low white cell count, thrombocytopenia, and elevated liver enzymes (Bhave, Rajput \& Bhave, 2015). Fatality of the dengue fever occurs when it progresses into dengue haemorrhagic fever, which if not controlled, leads to dengue shock syndrome causing multi organ damage and ultimately death (World Health Organization, 2015).

Aedes Aegypty and Aedes Albopicture mosquitoes are the transmitter of classical dengue fever and dengue haemorrhagic fever in many urban areas of South-east Asia, and both are present indoors and outdoors (Chen, et.al, 2005). Aedes Aegypty was found to be stronger than expected so far, where research indicates that they can live in dirty water, can fly farther and are active until evening (Hadi, 2011).

Increase of dengue cases are subjected to many factors. Barclay (2007) and Hii et.al (2009) identified that more rainfall in certain areas and warmer temperatures overall are providing optimal conditions for mosquitos to breed and expand into new territories. Significantly, Malaysia's equatorial climate which is hot and humid throughout the year with the average rainfall of $250 \mathrm{~cm}$ and average temperature $27^{\circ} \mathrm{C}$ is a perfect condition for Aedes mosquito to breed.

Evidently in Malaysia 70 to $80 \%$ of the reported dengue cases came from the high dense population and rapid development activities of the urban area (Ministry of Health, 2010). Nevertheless, a recent study highlighted that similar seroprevalence rates between urban and rural samples indicate that dengue no longer is confined to urban areas only and with the high dengue immunoglobin $\mathrm{G}(\operatorname{IgG})$ serpositivity found in the Malaysian population, dengue endemic is bound to remain longer (Muhammad Azami et al 2011).

Cheong, Leitao, and Lakes (2014) found that human settlements and nonagricultural areas largely determined the occurrence of dengue cases. Aedes 
mosquitoes were found indoors and outdoors in human settlements, especially in culverts, water compartments, metal drums, plastic drums, pails, gully traps, discarded containers, and solid-waste dumbs, open-spaces, construction sites, and factories. Flawed building structural designs are claimed to become one of the major contributing factors of dengue cases upsurge, as claimed and reported by many authorities such as Ministy of Health (Astro Awani, 2014; Malaysian Insider, 2014), Mesyuarat Jawatankuasa Peringkat Kebangsaan mengenai Denggi (Bernama, 2014), World Health Organization (2014), as well as, few academic researchers; Yee (2014) and Omonikweinka \& Iyagba (2005). However, the claim is yet to be empirically proven in the academic literature. This has become a research gap that seeks critical attention from academia, hence, drives this study with the aim to prove the claim through an empirical study by identifying Aedes breeding sites on building structures. Practically, it would be very useful and beneficial in guiding the policy makers in tackling the root causes of escalating dengue cases in Malaysia, and potentially to the other tropical climate regions with similar climate characteristics. Community empowerment in identifying breeding places is a key in dengue prevention activity and findings of this study helps in highlighting potential areas thus strengthening the overall dengue preventive framework.

\section{METHODOLOGY}

Three different sites in Lembah Pantai were selected for a building condition assessment in order to identify Aedes breeding spots on high rise residential buildings. These sites were identified by the Ministry of Health as dengue hotspots in 2014 based on the most frequent dengue cases reported.

The first site was a condominium that has 4 numbers of blocks, with 18 floors, and 316 of house units, with approximately 1,364 residents. The second site was a flat of People's Housing Program (Program Perumahan Rakyat, PPR) consists of 2 blocks of 4 floors, with a total of 64 house units, and populated by approximately 320 residents. The third site was also a PPR building of 4 blocksapartments, with 13 floors on each block which consists of 320 house units for 1,280 residents.

Approvals from the local authorities and the residences' Joint Management Body (JMB) were received to assess the building from the ground level to the roof top. In a period of 3 months, 5 visits were conducted on separate occasions at each site with the aim to identify the building elements that has become Aedes breeding spots. Each visit was participated by 6 researchers. Inspection covered outdoor compound, which include potential building elements such as roof, gutter, drain, toilet, corridor and other parts that have been identified as areas that are prone to mosquitoes breeding. Assessment of the findings of mosquito breeding spots to this building was done from top to bottom. Samples of larva found at the breeding spots were collected and tested to ensure the type 
Nurshuhada Zainon, Faizul Azli Mohd Rahim, Dalila Roslan \& Azlan Helmy Abd-Samat

Aedes Breeding Preferences for Urban High-Rise Building Planning Considerations in Malaysia

of larva belongs to Aedes. The findings were tabulated in a table form to see the commonalities of the breeding spots.

\section{RESULTS}

Of the total 5 visits in the each selected sites, Aedes larva were detected in all sites which mainly found on gutter, flat roof surfaces, floor finishes, gully traps, cracked slab, trench, drainage, piping, and outlets. From Table 1, gutters were found to be the spot with highest occurrence where out of all the number of inspections, $100 \%$ of samples were found positive. Other commonest breeding habitats for Aedes in order of preference were in flat roof surfaces, piping and outlets, blocked drainage, uncovered drainage, and poor gradients of drainage. Additionally, gully-trap related conditions show frequent spots for Aedes. The flat roof surfaces showed a surprising habitat for Aedes, where it was found on all the inspected sites; this had never been reported before. The inspections result also revealed that a large proportion of the positive sites harboured mostly on the same building elements (Figure 1), though different number of occurrences. Frequencies below than $50 \%$ is associated with less risk of Aedes breeding, therefore it was not indicated as an ideal Aedes breeding spot.

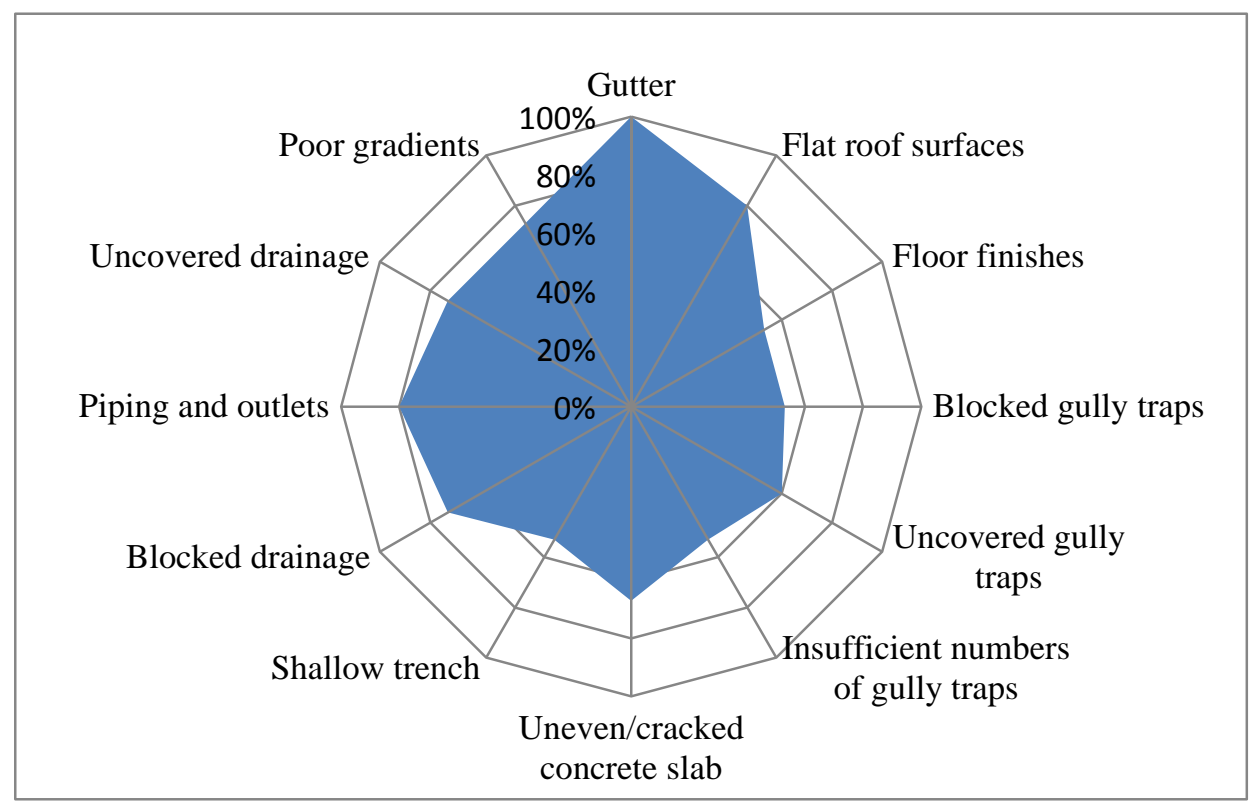

Figure 1: Commonalities of the Aedes breeding spots 
PLANNING MALAYSIA

Sustainable Urban Development

Table 1: Aedes breeding spots found on each site in different visits

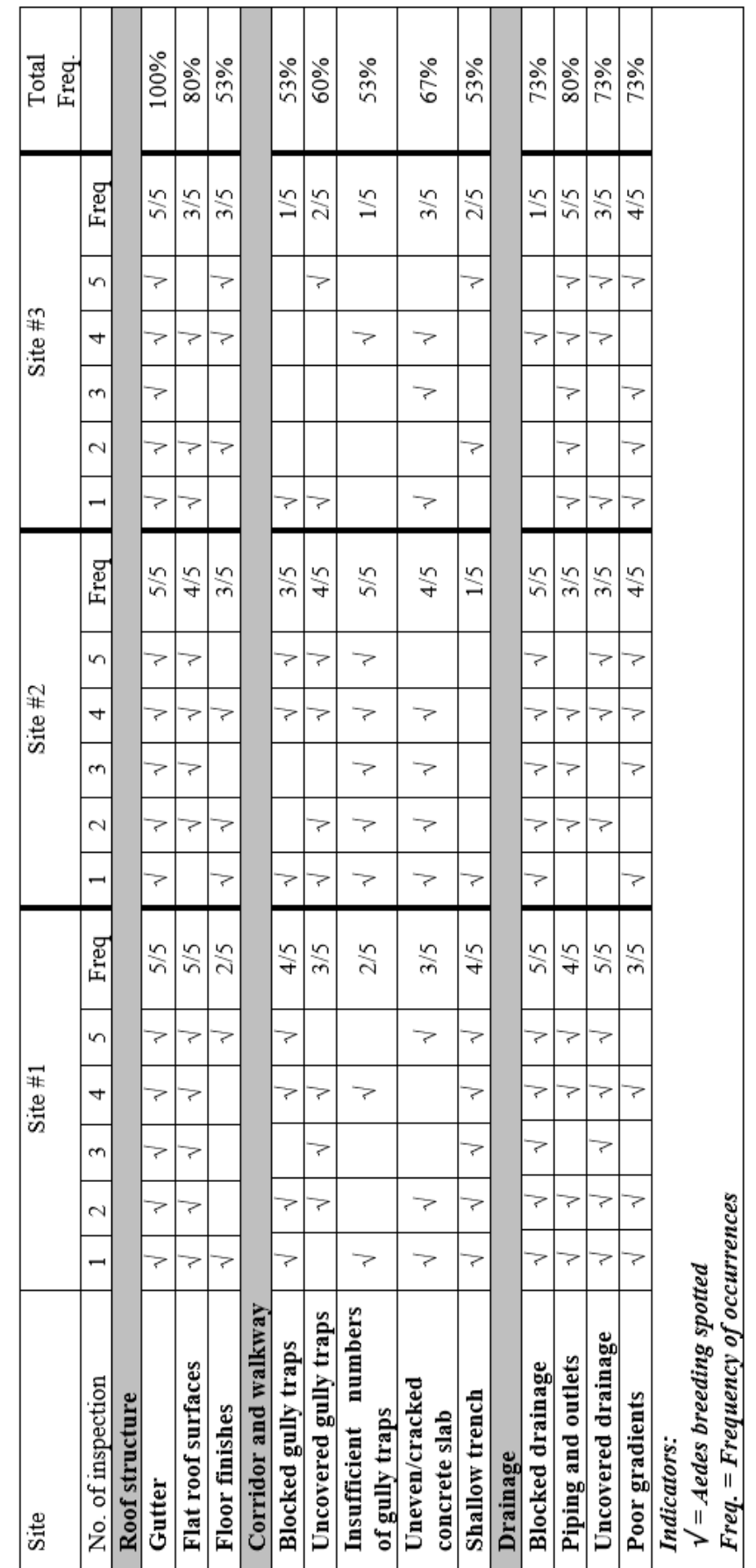


Nurshuhada Zainon, Faizul Azli Mohd Rahim, Dalila Roslan \& Azlan Helmy Abd-Samat

Aedes Breeding Preferences for Urban High-Rise Building Planning Considerations in Malaysia

\section{Gutter}

Roof has turned out the most common building element that contains Aedes breeding spot, especially on gutters (Figure 2(A)). Uncovered gutters were exposed to open space thus causing the rubbish, leaves, debris, and dust to fall into the gutter and block the movement of the water. This has resulted to blocked rainwater outlets, too. The gutter is made of iron, and they have rusted. Iron has comparatively low heat conductivity, means that it absorbs heat and dissipates heat at a slower rate. Thus, when the water is accumulated in the gutter, the slow rate of heat absorption by the gutter will cause the water to evaporate at a slower rate too. In other words, it has contributed to an ideal home for the mosquitoes to breed. In addition, the outlets size is too small which has encouraged algae growth and dirt deposition; these in return trapped the water flow. Another factor that contributes to the breeding spot is the lack of steep gradient level to channel the flow of water.

\section{Flat Roof Structure}

Uneven surfaces on the flat roof structure cause water stagnation (Figure 2(B)) Flat roofs should have constructed with a slight slope to allow rain water to drain off the roof. However, due to uneven surfaces, it causes water accumulation. Thus, it promotes the growth of green algae on concrete floor and this provides ideal water temperature for the mosquitos to breed, especially on some covered surfaces. Furthermore, water tanks that were located on the rooftop were leaked due to low maintenance.

\section{Floor Trench}

Insufficient gradient of floor trench causes the water to become stagnated. Furthermore, the trenches were blocked by debris and it causes water accumulation.

\section{Gully Trap}

Uncovered gully traps allow debris into the gully traps and resulting to blockage of gully traps (Figure 2(C)). Blocked gully traps, restricts rain water from flowing into the designated drain and may overflow through the gully trap opening; this will result into having stagnant water on the building apron or floor. Some of the large open areas have no gully traps to channel the rainwater from upstairs to the drainage. This large open area is normal for having a drop of around $25 \mathrm{~mm}$ to the normal ground floor level, which have enough capacity to create a high potential breeding spots. The water seal in the water traps becomes the house for mosquitos. 
PLANNING MALAYSIA

Sustainable Urban Development

\section{Floor Finishes}

At roof level, there are many empty spaces between the roof finishes which causes the rainwater unable to flow into a correct direction and discharge off from the building (Figure 2(D)). The rainwater will stagnant in gaps between the floor finishes or below the floor finishes. The arrangement fault of tiles encourages the growth of plant and increases the difficulties for water to flow out as the plant will act as a blockage for water movement.

\section{Apron}

Cracked apron creates a hole between the concrete of the apron and causes water stagnant (Figure 2(E)). The apron that was built with flat shaped design that has caused rainwater stagnant on the finishes, and there was no down water pipe at sides of the building to let stagnant water flows out from apron.

\section{Piping and Outlets}

Piping outlets were not connected direct to the drainage system resulting to water overflow and accumulation on the uneven floor surfaces (Figure 2(F)). It also causes flash flood in the dwelling area because the water is pouring freely on the concrete bed of the pavement instead of directly discharge the water into the sewage. Lack of repair of leaky pipes causes' small water ponds everywhere, in addition to, lack of maintenance of corridors' floors encourages green algae growth which creates ideal water temperature for the mosquitos to breed. In addition, the limited number of outlets creates slow water flow, too. The L-shaped rainwater down pipe used instead of the straight flow pipe also resulted in ideal breeding spots for Aedes. Reason being, the L-shaped pipe has poor gradient whereas the straight flow pipe could flow rainwater directly from the rooftop to the ground floor.

\section{Drainage}

Poor gradient of drainage prevents water from flowing smoothly resulting to blockage and stagnation of water. Drain covers, which are screwed to the ground, makes it impossible to be removed for cleaning. There were also some hips near the places which dirt can flow with the water to the drains and led to blockage to the flow of water. Cracked drainage causes the growth of trees and their continued growth made the drain cracked under the heavy load (Figure 2(G)). The cracked becomes location of water stagnation.

\section{Open Space}

A huge water ponding in yard located at the centre and open area, surrounding by the residents' houses with total coverage is $8.68 \mathrm{~m} \times 4.75 \mathrm{~m}$ (Figure $2(\mathrm{H})$ ). The surface of yard is covered by a type of soil called sandy loam soil. Sandy loam 
Nurshuhada Zainon, Faizul Azli Mohd Rahim, Dalila Roslan \& Azlan Helmy Abd-Samat

Aedes Breeding Preferences for Urban High-Rise Building Planning Considerations in Malaysia

soil contains some silt and a small amount of clay. This kind of soil has moderately high water retention and moderate drainage erosion.

\section{Unwanted Building Element}

Unwanted hollow metal were found in several locations and they keep stagnant water. The locations of the hole under the zinc roof protect the water pond from the sunlight, hence becomes an ideal home for mosquitos (Figure 2(I)),

\section{DISCUSSION}

Table 2 shows the summary of Aedes breeding areas that were spotted during the observations in three case studies. The breeding spots were spotted at the rooftop, as well as, on the ground floor. Beside suggestion of performing more frequent maintenance, there are some rectifications that could be done in order to avoid stagnation and accumulation of water in those areas. Gutters, gully traps, and flat roof surfaces were found most as Aedes habitats. Most of Aedes favourite spots require maintenance and having scheduled maintenance of building hinders the breeding of Aedes. Frequent cleaning of water ponding in any building elements should be conducted to ensure a healthy environment free from dengue. However, for some elements, enhanced method of constructions should be embarked to ensure buildings' contribution for sustainable living in urban environment.

\section{Gutters}

Gutters functions as a rainwater collector from the roof of a building and diverts the water away from the structure. It was found that it has become a key container for Aedes not just in Malaysia, but also in Australia (Montgomery \& Ritchie 2002), especially due to blockage. Few mitigation measures could be undertaken. The surface of the gutter should be ensured smooth and flat without any pocket present so water can flow_smoothly and this can prevent water stagnation. It should be constructed with gradient inclines minimum 12 millimetres for every 1 meter in the direction of the water flow (JKR, 2005). With this, the gutter should drain completely if the inclination is correctly set. The gutter can be installed with K-styled gutter due to its design properties that can hold more rainwater than other gutter despite having the same diameter. However, to prevent water blockage in gutter, drilling tiny holes in the gutter will allow the flowing water in the gutter to flow out of the gutter (Figure 1(J)). This will prevent the water from being accumulated in the gutter at any point and hence prevent the water in the gutter to become stagnated and causes the breeding of Aedes mosquitoes. Furthermore, gutter mesh screen could be installed to prevent leaves and debris and from falling into the gutter and impedes the flow of water. The gutter mesh screen can be found in three different types: those that screen and filter; those that block and fill; and those that separate water from debris by means of surface 
PLANNING MALAYSIA

Sustainable Urban Development

tension. Gutters should be installed with a solid, flexible drain tile that runs underground and extended downhill to safely exit via a pop-out outlet.

Figure 1: Aedes larvae spotted areas

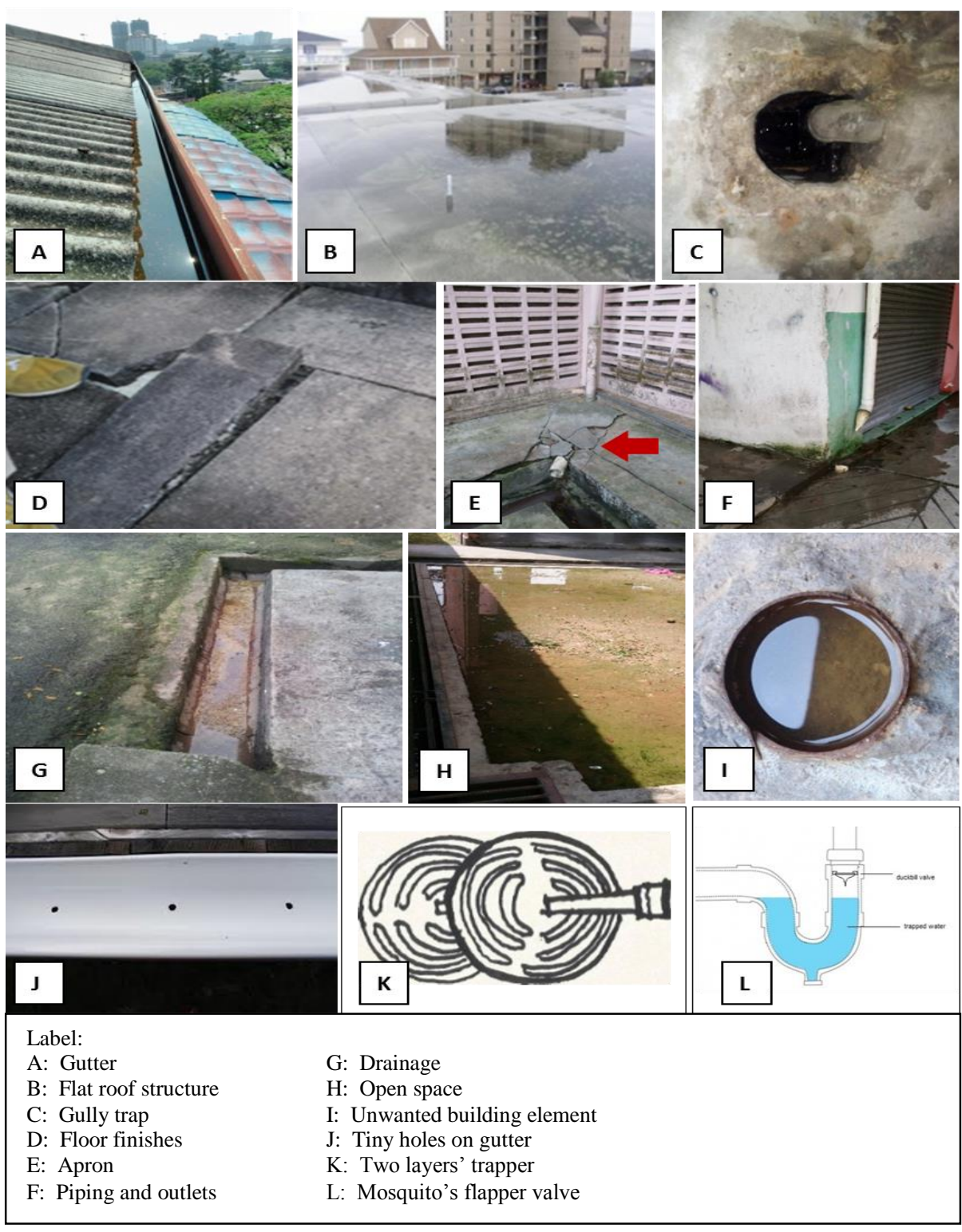


Nurshuhada Zainon, Faizul Azli Mohd Rahim, Dalila Roslan \& Azlan Helmy Abd-Samat

Aedes Breeding Preferences for Urban High-Rise Building Planning Considerations in Malaysia

\section{Roof Top Surfaces}

Ponding on the low-lying parts of a flat roof has an implication in providing Aedes breeding area. To overcome this, concrete is added to one side of the roof which is away from nozzle outlet of the rain water down pipe to increase the sloping gradient of the roof so that water has higher chance to flow towards the nozzle outlet of rain water down pipe. The concrete surface of flat roof is plastered so that the surface is much smoother and rainwater, sand, soil, dirt and debris can flow fast and smoothly towards the rain water down pipe. Alternatively, a French drain system could be installed and plants could be grown at the rooftop yard. The French drain consists of perforated drain pipe which lying at the bottom of trench to enable it vents water that seep down through the gravel or big rocks quickly (Mahan, Massa, White \& Young 2002). It is a relatively simple and cost effective way of draining land, and it does not require specialist tools or complicated equipment.

\section{Flat Shaped Apron}

Designing a slope to the flat shaped apron would allow the flow of water and prevents stagnation. By having cement render with angle $15^{\circ}$ and add gutter beside the apron can reduce the chance for Aedes breeding. Moreover, by increasing the numbers of rain water down pipes for the water to flow down can reduce the breeding spot for mosquitos in that particular place.

\section{Gully Trap}

Trappers consist of two layers of grating could be very beneficial (Figure 1(K)). The first layer grating has larger holes and the second layer has finer holes. A rod is constructed to connect both layers of grating. The new design of trapper is believed that it can increase the efficiency of water flowing by trapping objects which cause blockage to occur.

\section{Down Pipe}

The downpipe for the gutter at the rooftop level is not directly connected to the floor trap downstairs. The downpipe goes vertically down and stops on the floor, wherever the downpipe is placed. The floor trap may be on the opposite side of the space or on the same side but on different ends. To ensure that the flow of rainwater is safely channelled to the drain, the rainwater downpipe must be installed with extra rainwater downpipe connecting the pipe straight to the building. Mosquitoes swing valve is designed to prevent mosquitoes' penetration into the water trap. This could avoid mosquitoes from breeding in the trapped water. The way mosquito's flapper valve functions are similar to swing valve principle in preventing backflow of water in the drainage system and scupper flapper which installed in a boat (Figure 1(L)). Duckbill valve is among the devices that are widely utilized to prevent backflow or act as one-way valve. The 
simplest duckbill valve usually includes a collar and valve member which shaped like the beak of the duck. Duckbill valve is placed to prevent access of mosquitoes into the water seal.

\section{Drainage}

Permeable concrete act like porous medium rather than solid, impermeable block and this allows water to seep through the gap in the concrete (Gunderson, 2008). By using drain cover made from permeable concrete, only water will penetrate through the cover then to the drainage system leaving out substances like rubbish, leaves and debris from falling into the drain and cause drainage blockage. Permeable drain cover also can prevent mosquitoes from breeding in the drain if any stagnant water available.

Table 2: Summary of the Aedes breeding spots with high occurrences

\begin{tabular}{|l|c|c|c|}
\hline Building element & Site \#1 & Site \#2 & Site \#3 \\
\hline Roof structure & $\sqrt{ }$ & $\sqrt{ }$ \\
\hline Gutter & $\sqrt{ }$ & $\sqrt{ }$ & $\sqrt{ }$ \\
\hline Flat roof surfaces & & $\sqrt{ }$ & $\sqrt{ }$ \\
\hline Floor finishes & $\sqrt{ }$ & $\sqrt{ }$ & \\
\hline Corridor and walkway & $\sqrt{ }$ & $\sqrt{ }$ & \\
\hline Blocked gully traps & & $\sqrt{ }$ & \\
\hline Uncovered gully traps & $\sqrt{ }$ & $\sqrt{ }$ & \\
\hline $\begin{array}{l}\text { Insufficient numbers of gully } \\
\text { traps }\end{array}$ & $\sqrt{ }$ & \\
\hline Uneven/cracked concrete slab & $\sqrt{ }$ & $\sqrt{ }$ \\
\hline Shallow trench & $\sqrt{ }$ & $\sqrt{ }$ & $\sqrt{ }$ \\
\hline Drainage & $\sqrt{ }$ & $\sqrt{ }$ & $\sqrt{ }$ \\
\hline Blocked drainage & $\sqrt{ }$ & $\sqrt{ }$ \\
\hline Piping and outlets & & & \\
\hline Uncovered drainage & & \\
\hline Poor gradients &
\end{tabular}

\section{CONCLUSION}

This study represents observed findings of common Aedes breeding spots on high-rise buildings. As presented in the Table 2, we found commonalities in building elements that act as catalysts for Aedes breeding, mainly on roof structure, corridor and walkway, and drainage. Interestingly, the emergence of new factors which are the uneven flat floors and rooftop; uniquely occurring in Malaysia and creates avenue for further research to comprehend and support this finding. This research has proved claims made by local authorities and researchers, especially the Malaysia Ministry of Health, where building elements are contributing to dengue cases upsurge by providing ideal conditions for Aedes 
Nurshuhada Zainon, Faizul Azli Mohd Rahim, Dalila Roslan \& Azlan Helmy Abd-Samat

Aedes Breeding Preferences for Urban High-Rise Building Planning Considerations in Malaysia

to breed. However, it was not solely caused by the design of the buildings, but it was mainly related to the neatness and accuracy of a builder's works during construction. For instance, based on the Standard and Specifications for Building Works (JKR, 2005), gutters' gradient should be built with an inclination of minimum 12 millimetres for every 1 meter in the direction of the flow. Nonetheless, research has shown that the gutter was built with poor gradient. Another example is the hollow metal that was found on the floor in several locations; this component has no purpose and could be eliminated to avoid water stagnation.

The findings demand for further research in investigating environmental and physical condition that make each component as an ideal breeding space for Aedes; follow-up researches can provide an understanding of micro elements of building design which contributes to the macro scale of human sustainable living environment. It will also impact on how designers design a building; consequently becomes one of considerations that need to be taken during planning stage.

There are two main potential implications of this research. Firstly, these findings elucidate a link between the importance of non-health factor which is the construct of a building, contributing to a life threatening disease which is dengue. In technical terms, building designs can be further improved, as it seeks the application of construction technologies. Preventing Aedes should start and involve the whole life cycle of planning, constructing and maintaining of any building project.

Secondly, these findings further reaffirms the importance of the findings to be considered as parts of the checklist items in building plan, as well as, to comprehend the Aedes Control Guideline in Construction Sites 2015. Collaboration between health aspect and technical sector provides a deeper understanding on the_potential breeding points as highlighted in this study; the collaboration will help shape relevant primary prevention program across the community. This knowledge would only be useful once translated into the right attitude and action. With existing search and destroy programmes this useful information helps the community in tailoring their Aedes search towards relevant building features and in the long run also save cost and time in effectively combating dengue. 
PLANNING MALAYSIA

Sustainable Urban Development

\section{REFERENCES}

Abubakar, S. \& Shafee, N. (2002). Outlook of dengue in Malaysia: a century later. Malaysian Journal of Pathology, 24(1), 23-28.

Muhammad Azami, N.A., Salleh, S.A., Neoh, H.M., Syed Zakaria, S.Z. \& Jamal, R. (2011). Dengue epidemic in Malaysia: Not a predominantly urban disease anymore. BMC Research Note, 4(1), 216.

Astro Awani (2014, December 10). Selangor terima bantuan kerajaan pusat atasi masalah denggi. Retrieved from: http://www.astroawani.com/beritamalaysia/selangor-terima-bantuan-kerajaan-pusat-atasi-masalah-denggi-50002.

Astro Awani (2015, March 31), Demam denggi meningkat kepada 31,535 kes dalam tempoh 3 bulan - Muhyiddin. Retrieved from: http://www.astroawani.com/berita-malaysia/demam-denggi-meningkatkepada-32-535-kes-dalam-tempoh-tiga-bulan-muhyiddin56831?_ga=1.268826097.1438295964.1477984460

Barclay, E. (2007). Climate Change Spurring Dengue Rise, Expert Say. Retrieved from http://news.nationalgeographic.com/news/2007/09/070921-denguewarming.html.

Bernama (2015). Demam denggi meningkat kepada 32, 535 kes dalam tempoh 3 bulan Muhyiddin. Astro Awani, Kuala Lumpur.

Bernama (2014, Novermber 4)). Denggi: Muhyiddin pengerusi Mesyuarat Jawatankuasa Peringkat Kebangsaan. Berita Harian, Kuala Lumpur.

Bhave, S., Rajput, C. \& Bhave, S. (2015). Clinical profile and outcome of dengue fever and dengue haemorrhagic fever in paediatric age group with special reference to WHO Guidelines 2012 on fluid management of dengue fever. International Journal, 3(4), 196-201.

Cheong, Y.L., Leitao, P.J. \& Lakes, T. (2014). Assessment of land uses factors associated with dengue cases in Malaysia using Boosted Regression Trees. Spatial and Spatio-temporal Epidemiology, 10(July), 75-84.

Chen, C.D., Benjamin S., Saranum, M.M., Chiang, Y.F., Lee, H.L., Nazni, W.A. \& Sofian-Azirun, M. (2005). Dengue vector surveillance in urban residential and settlement areas in Selangor, Malaysia. Tropical biomedicine, 22(1), 39-43.

Gunderson, J. (2008). Pervious pavements: New findings about their functionality and performance in cold climates. Stomwater, September.

Hadi, U.K. (2011). Mosquitoes cause dengue able living in dirty water, in Parasitology and Entomology Health, Paper presented at The Insect Seminar, March 18, Cibinong Science Center, Bogor.

Hii, Y.L., Rocklöv, J., Ng, N., Tang, C.S., Pang, F.Y. \& Sauerborn, R. (2009). Climate variability and increase in intensity and magnitude of dengue incidence in Singapore. Global Health Action, 2.

JKR (2005). Standard and Specifications for Building Works. Jabatan Kerja Raya Kuala Lumpur.

Mahan, E., Massa, B, White, M. \& Young, C. (2002). Rooftop runoff collection for groundwater recharge or reuse. Proceedings of the Water Environment Federation (WEFTEC 2002). Water Environment Federation. 
Nurshuhada Zainon, Faizul Azli Mohd Rahim, Dalila Roslan \& Azlan Helmy Abd-Samat

Aedes Breeding Preferences for Urban High-Rise Building Planning Considerations in Malaysia

Malaysian Insider (2014, December 9). Putrajaya komited bantu Selangor tangani denggi. Retrieved from http://www.themalaysianinsider.com/bahasa/article/ putrajaya-bantu-selangor-tangani-denggi.

Ministry of Health (2010). Clinical Practice Guidelines: Management of Dengue Infection in Adults (Revised 2nd Edition). Putrajaya: Ministry of Health.

Mohd-Zaki, A.H, Brett, J., Ismail, E. \& L'Azou, M. (2014). Epidemiology of Dengue Disease in Malaysia (2000-2012): A Systematic Literature Review. PLoS Negl Trop Dis, 8(11), e3159.

Montgomery, B \& Ritchie, S.A. (2002). Roof gutters: a key container for Aedes Aegypti and Ochlerotatus Notoscriptus (Diptera: Culicidae) in Australia. The American Journal of Tropical Medicine and Hygiene, 67(3), 244-246.

Omonikweinka, R.R. \& Iyagba, A. (2005). The Menace of Sick Buildings: A Challenge to All For Its Prevention and Treatment. Lagos: University of Lagos Press.

World Health Organization (2015). Dengue and severe dengue. Retrieved from http://www.who.int/mediacentre/factsheets/fs117/en/.

Yee, F.P. (2014, August 24). Authorities need to get to root cause of dengue fever problem. The Star, Kuala Lumpur. 